\title{
THE CLINICAL VALUE OF THE TREPONEMA IMMOBILIZATION TEST IN THE DIAGNOSIS AND CONTROL OF SYPHILIS
}

\author{
BY \\ C. W. CHACKO \\ From the Bacteriology Department, St. Mary's Hospital Medical School, London
}

(RECEIVED FOR PUBLICATION JANUARY 31, 1953)

Ever since the first report of the Wassermann reaction in 1906 the physician has often been faced with the problem of correctly interpreting and coordinating with the clinical findings the results of various standard serological tests for syphilis. Improvements in the methods and materials, particularly the purification of the antigen in the form of cardio'ipin, have not completely eliminated the false positive reactions that are sometimes given by both complement fixation and flocculation tests. This is not surprising in view of the fact that all these tests are based on an empirical reaction between a non-specific antigen consisting of a lipoidal tissue extract and a so-called antibody in syphilitic serum called reagin.

Attempts to grow virulent Treponema pallidum in artificial culture medium and thereby provide sufficient specific antigen for serological tests have hitherto failed. However, a new approach to the problem was made when Nelson and Mayer (1949) devised the Treponema pallidum immobilization (T.P.I.) test for syphilis. Virulent $T$. pallida were extracted from infected rabbit testes into a special anaerobic medium in which they were kept alive and viru'ent for several days. This relatively tissuefree suspension of mobile $T$. pallida was immobilized when mixed with syphilitic serum in vitro in the presence of active complement. No such immobilizing effect was obtained with normal or serologically false positive sera or in the absence of fresh complement. Since a virulent strain of T. pallidum (Nichols' strain) was used, the T.P.I. test was considered a specific test for syphilis involving a specific anti-treponemal antibody. This antibody was demonstrated to be distinct from the Wassermann antibody which could be absorbed from the syphilitic serum with lipoidal tissue extract antigen leaving the immobilizing antitreponemal antibody intact.

In the present study 532 specimens of blood sera and 56 of cerebrospinal fluid from syphilitic and non-syphilitic persons have been examined with four tests in parallel, namely the T.P.I. test, the Wassermann test, the Kahn test, and the Venereal Diseases Reference Laboratory (U.S. Public Health Service) (V.D.R.L.) slide flocculation test. The results obtained confirm in general the findings of earlier workers (Nelson and Mayer, 1949 ; Nelson, Zheutlin, Diesendruck, and Austin, 1950 ; Nelson and Diesendruck, 1951 ; Magnuson and Thompson, 1949 ; Mohr, Moore, Nelson, and Hill, 1950 ; Durel, Sausse, Collart, Roiron, and Borel, 1951) so far as the specificity and sensitivity of the T.P.I. test in the diagnosis of syphilis is concerned. From the results obtained the practical value of the T.P.I. test to venereologists in this country is assessed.

\section{Materials and Methods}

Most of the specimens of sera and cerebrospinal fluid were obtained from the Special (V.D.) Clinic of St. Mary's Hospital. The sera giving false positive tests for syphilis came mostly from the Medical Research Council Venereal Disease Reference Laboratory (London). The leprosy sera were flown from the Leprosy Clinic of the Christian Medical College Hospital, Vellore, Madras, India. The sera from cases of bejel were received by air from the W.H.O. Bejel Projects Centre in Iraq. Sera from yaws cases were received from the Treponematosis Control Centre at Bangkok, Siam.

Fasting patients were bled aseptically at least 10 days after the end of treatment with penicillin or other treponemicidal drugs. The sera after separation from the blood clot were stored in $5 \mathrm{ml}$. screw-capped bottles at $-20^{\circ} \mathrm{C}$. until they were tested. The sera and cerebrospinal fluid were tested by all the four tests simultaneously as far as practicable.

The Wassermann test was done according to the technique of Adami, Andrewes, Bulloch, and Harrison (1918). The Kahn test was done accord- 
ing to the standard Kahn technique (Kahn, 1925), except that only one tube containing $0.025 \mathrm{ml}$. of the antigen and $0.15 \mathrm{ml}$. of the serum was used. The V.D.R.L. slide test was done following the technique of Harris, Rosenberg, and Riedel (1946) and Harris, Rosenberg, and Del Vecchio (1948) using cardiolipin antigen. The T.P.I. test was performed according to the method of Nelson and Mayer (1949) with minor modifications (Chacko, $1952)$ to suit the conditions in Britain.

The sera and cerebrospinal fluids were classified into various diagnostic categories on clinical and historical evidence and on the results of the standard test for syphilis. Most of the syphilitic patients had had standard courses of anti-syphilitic treatment and their sera and cerebrospinal fluid were tested in this study at periods varying from a few months to many years after treatment. In the tabulation of results weakly positive reactions have been grouped with the positive findings.

In the comparative study of the four tests the sensitivity of a test was rated by the percentage of positives in known cases of syphilis, while specificity was rated as the percentage of negatives in cases not showing any evidence of syphilis.

\section{Results}

Sensitivity of the T.P.I. Test.-Table I shows the relative sensitivity of the four tests in 35 cases of primary syphilis. In eight cases of untreated primary syphilis the T.P.I. test compared poorly with standard tests as regards sensitivity. In 27 treated primary cases treatment apparently affected the sensitivity of the standard tests more than the T.P.I. test.

TABLE I

COMPARATIVE SENSITIVITY OF FOUR TESTS IN 35 CASES OF PRIMARY SYPHILIS

\begin{tabular}{c|c|c|c|c|c}
\hline & \multicolumn{2}{|c|}{ Untreated Primary } & \multicolumn{3}{|c}{ Treated Primary } \\
\cline { 2 - 5 } Tests & $\begin{array}{c}\text { No. } \\
\text { Tested }\end{array}$ & Positive & $\begin{array}{c}\text { No. } \\
\text { Tested }\end{array}$ & Positive & $\begin{array}{c}\text { Sensitivity } \\
(\%)\end{array}$ \\
\hline $\begin{array}{c}\text { T.P.I. } \\
\text { W.R. }\end{array}$ & 8 & 2 & 27 & 6 & $22 \cdot 2$ \\
$\begin{array}{c}\text { Kahn } \\
\text { V.D.R.L. }\end{array}$ & 8 & 5 & 27 & 0 & 0 \\
cardiolipin & 8 & 5 & 27 & 2 & $7 \cdot 4$ \\
\hline
\end{tabular}

The T.P.I. test was positive in all four cases of untreated secondary syphilis; the standard tests were also positive in those four cases. In 10 cases of treated secondary syphilis treatment again seemed to affect the sensitivity of standard tests more than the T.P.I. test (Table II). The T.P.I. test was positive in all 46 cases of treated late
TABLE II COMPARATIVE SENSITIVITY OF FOUR TESTS IN 14
CASES OF SECONDARY SYPHILIS

\begin{tabular}{|c|c|c|c|c|}
\hline \multirow[b]{2}{*}{ Tests } & \multirow{2}{*}{$\frac{\text { Untreated }}{\text { No. Tested }}$} & \multirow{2}{*}{$\frac{\text { Secondary }}{\text { Positive }}$} & \multicolumn{2}{|c|}{ Treated Secondary } \\
\hline & & & No. Tested & Positive \\
\hline $\begin{array}{l}\text { T.P.I. } \\
\text { W.R. } \\
\text { Kahn }\end{array}$ & $\begin{array}{l}4 \\
4 \\
4\end{array}$ & $\begin{array}{l}4 \\
4 \\
4\end{array}$ & $\begin{array}{l}10 \\
10 \\
10\end{array}$ & $\begin{array}{l}6 \\
2 \\
4\end{array}$ \\
\hline cardiolipin & 4 & 4 & 10 & 3 \\
\hline
\end{tabular}

syphilis (tertiary, cardiovascular, and neuro syphilis). These cases had all been serologically? positive before treatment was begun. The standard ${ }_{\omega}^{\circ}$ tests, except in five cases of tertiary syphilis, gave a lower proportion of positive results (Table III). N

TABLE III

COMPARATIVE SENSITIVITY OF FOUR TESTS IN 46 CASES OF TREATED LATE SYPHILIS

\begin{tabular}{|c|c|c|c|c|c|c|c|c|c|}
\hline \multirow[b]{2}{*}{ Tests } & \multicolumn{2}{|c|}{$\begin{array}{l}\text { Tertiary } \\
\text { Syphilis }\end{array}$} & \multicolumn{2}{|c|}{$\begin{array}{l}\text { Cardio- } \\
\text { vascular } \\
\text { Syphilis }\end{array}$} & \multicolumn{2}{|c|}{$\begin{array}{l}\text { Neuro- } \\
\text { syphilis }\end{array}$} & \multicolumn{3}{|c|}{ Total } \\
\hline & Z & $\stackrel{0}{:}$ & Z & 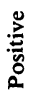 & 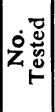 & 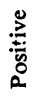 & 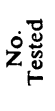 & $\begin{array}{l}\stackrel{0}{\vdots} \\
: \\
0 \\
0 \\
0\end{array}$ & 言 \\
\hline $\begin{array}{c}\text { T.P.I. } \\
\text { W.R. } \\
\text { Kahn } \\
\text { V.D.R L. } \\
\text { cardiolipin }\end{array}$ & $\begin{array}{l}5 \\
5 \\
5 \\
5\end{array}$ & $\begin{array}{l}5 \\
5 \\
5 \\
5\end{array}$ & $\begin{array}{l}7 \\
7 \\
7\end{array}$ & $\begin{array}{l}7 \\
4 \\
6\end{array}$ & $\begin{array}{l}34 \\
34 \\
33 \\
\\
34\end{array}$ & $\begin{array}{l}34 \\
17 \\
24 \\
\\
29\end{array}$ & $\begin{array}{l}46 \\
46 \\
45 \\
46\end{array}$ & $\begin{array}{l}46 \\
26 \\
35 \\
41\end{array}$ & $\begin{array}{c}100 \\
56 \cdot 5 \\
77 \cdot 8 \\
89 \cdot 1\end{array}$ \\
\hline
\end{tabular}

Tables IV and V show that in treated latent and congenital syphilitic cases the T.P.I. test had aa higher sensitivity rating than the standard tests.

TABLE IV

COMPARATIVE SENSITIVITY OF THE FOUR TESTS IN 101 CASES OF TREATED LATENT SYPHILIS

\begin{tabular}{|c|c|c|c|}
\hline Tests & $\begin{array}{l}\text { Number } \\
\text { Tested }\end{array}$ & Positive & $\underset{(\%)}{\text { Sensitivity }}$ \\
\hline $\begin{array}{c}\text { T.P.I. } \\
\text { W.R. } \\
\text { Kahn } \\
\text { V.D.R.L. } \\
\text { cardiolipin }\end{array}$ & $\begin{array}{l}101 \\
101 \\
101 \\
101\end{array}$ & $\begin{array}{l}92 \\
62 \\
81 \\
81\end{array}$ & $\begin{array}{l}91 \cdot 1 \\
61 \cdot 4 \\
80 \cdot 2 \\
80 \cdot 2\end{array}$ \\
\hline
\end{tabular}

TABLE V

COMPARATIVE SENSITIVITY OF FOUR TESTS IN 21 CASES OF TREATED CONGENITAL SYPHILIS

\begin{tabular}{c|c|c|c|}
\hline Tests & $\begin{array}{c}\text { Number } \\
\text { Tested }\end{array}$ & Positive & $\begin{array}{c}\text { Sensitivity } \\
(\%)\end{array}$ \\
\hline T.P.I. & 21 & 15 & $71 \cdot 4$ \\
W R. & 21 & 7 & $33 \cdot 3$ \\
Kahn & 21 & 8 & 38 \\
V.D.R.L. & 21 & 9 & 43 \\
\hline
\end{tabular}


Specificity of the T.P.I. Test.-The proportion of positive T.P.I. results obtained with sera from 11 cases of yaws was much lower than would be expected, but they are equally low in all the four tests. It may be mentioned that these sera came from Bangkok, they arrived badly contaminated, and on preliminary testing they proved anticomplementary and treponemicidal. When filtered free of bacteria only two of the 11 sera gave positive T.P.I. tests (Table VI). These poor results.

TABLE VI

COMPARATIVE SENSITIVITY OF FOUR TESTS IN 11 CASES OF YAWS AND 15 CASES OF BEJEL

\begin{tabular}{|c|c|c|c|c|c|c|}
\hline \multirow[b]{2}{*}{ Tests } & \multicolumn{3}{|c|}{ Yaws } & \multicolumn{3}{|c|}{ Bejel } \\
\hline & $\begin{array}{l}\text { No. } \\
\text { Tested }\end{array}$ & Positive & $\begin{array}{l}\text { Sensiti. } \\
\text { vity }(\%)\end{array}$ & $\begin{array}{l}\text { No. } \\
\text { Tested }\end{array}$ & Positive & $\begin{array}{l}\text { Sensiti- } \\
\text { vity }(\%)\end{array}$ \\
\hline $\begin{array}{l}\text { T.P.I. } \\
\text { W.R. } \\
\text { Kahn } \\
\text { V.D.R.L. }\end{array}$ & $\begin{array}{l}11 \\
11 \\
11\end{array}$ & $\begin{array}{l}2 \\
1 \\
3\end{array}$ & $\begin{array}{r}18 \cdot 2 \\
9 \cdot 1 \\
27 \cdot 2\end{array}$ & $\begin{array}{l}10^{*} \\
10^{*} \\
14\end{array}$ & $\begin{array}{l}10 \\
10 \\
12\end{array}$ & $\begin{array}{l}100 \\
100 \\
85 \cdot 7\end{array}$ \\
\hline cardiolipin & 11 & 2 & $18 \cdot 2$ & 15 & 12 & 80 \\
\hline
\end{tabular}

* Five sera were haemoiysed and unsuitable for the T.P.I. and Wassermann tests.

may not have been due to the contamination and filtration as the T.P.I. antibody has been found to be fairly stable in the presence of bacterial contamination of the serum (Chacko, 1952). No definite conclusions are drawn from the results for want of complete data about these cases.

In the examination of 15 sera from cases of bejel more convincing results were obtained than in cases of yaws (Table VI). Five of the 15 sera were received haemolysed and T.P.I. and Wassermann tests could not be done on them ; the remaining 10 sera were positive by the T.P.I. test and the sensitivity of the standard tests was comparable with it.

The comparative specificity of the four tests with 289 non-syphilitic sera surveyed in this study is given in Table VII. The specificity of the T.P.I.

TABLE VII

COMPARATIVE SPECIFICITY OF FOUR TESTS IN 289 NON-SYPHILITIC CASES

\begin{tabular}{c|c|c|c}
\hline Tests & Number Tested & Negative & Specificity (\%) \\
\cline { 1 - 2 } T.P.I. & 289 & 287 & $99 \cdot 3$ \\
W.R. & 288 & 268 & 92 \\
Kahn & 287 & 248 & 86.4 \\
V.D.R.L. & 288 & 274 & $94 \cdot 8$ \\
cardiolipin & & & \\
\hline
\end{tabular}

test was only 0.7 short of $100 \%$, while the standard tests compared poorly with it.

The specific value of the T.P.I. test in the assessment of biological false positive reactions obtained
TABLE VIII

COMPARATIVE SPECIFICITY OF THE FOUR TESTS IN 48 SERA FROM UNTREATED CASES GIVING BIOLOGICAL FALSE POSITIVE TESTS FOR SYPHILIS

\begin{tabular}{c|c|c|c}
\hline Tests & Number Tested & Negative & Specificity (\%) \\
\hline T.P.I. & 48 & 46 & 96 \\
W.R. & 47 & 25 & $53 \cdot 2$ \\
Kahn & 46 & 7 & $15 \cdot 2$ \\
V.D R L & 47 & 33 & 70.2 \\
\hline
\end{tabular}

with standard tests is shown in Table VIII. Among the 48 sera were included 24 out of 37 specimens from cases of leprosy, 11 from persons with no history of any recent illnesses which are known to elicit faise positive tests for syphilis, five associated with pregnancy, and one each from disseminated lupus erythematosus, malignant lymphoma, vaccinia, subacute bacterial endocarditis, endometriosis, haemolytic anaemia, pityriasis rosea, and malaria. In this heterogeneous group the only positive T.P.I. tests occurred in two cases of leprosy. In these two cases concurrent infection with syphilis could not be completely excluded. The standard tests again gave a varying percentage of non-specific positive results characteristic of this group.

In 241 non-syphilitic sera, which included 109 from persons with no apparent disease, 34 from cases of gonorrhoea, 30 from ante-natal cases, 19 from non-specific urethritis, 13 from leprosy, nine from cancer, six from infectious mononucleosis, six from cases exposed to venereal diseases, three from aortic diseases, two from papilloma penis, and 10 from various other diseases, all the four tests, including the T.P.I. test, were negative.

Sensitivity of T.P.I. Test With Cerebrospinal Fluid.-The T.P.I. test with cerebrospinal fluid was positive in nine out of 12 cases of treated neurosyphilis and the sensitivity of the standard tests compared very well with it. In 20 specimens of cerebrospinal fluid from other stages of syphilis the T.P.I. and standard tests were all negative (Table IX). All the four tests were negative in 24 specimens of cerebrospinal fluid from diseases other than syphilis, including 12 from tuberculous meningitis, six from undiagnosed diseases, two from dis-

TABLE IX

COMPARATIVE SENSITIVITY OF THREE TESTS IN 52 SAMPLES OF SYPHILITIC C.S.F.

\begin{tabular}{|c|c|c|c|c|c|c|}
\hline \multirow[b]{2}{*}{ Tests } & \multicolumn{3}{|c|}{ Neurosyphi'is } & \multicolumn{3}{|c|}{ Other Stages of Syphilis } \\
\hline & $\begin{array}{l}\text { No. } \\
\text { Tested }\end{array}$ & Positive & $\begin{array}{l}\text { Sensiti- } \\
\text { vity }(\%)\end{array}$ & $\begin{array}{l}\text { No. } \\
\text { Tested }\end{array}$ & Positive & $\begin{array}{l}\text { Sensiti- } \\
\text { vity }(\%)\end{array}$ \\
\hline $\begin{array}{l}\text { T.P.I. } \\
\text { W.R. } \\
\text { V.D.R.L. } \\
\text { cardiolipin }\end{array}$ & $\begin{array}{l}12 \\
12 \\
12\end{array}$ & $\begin{array}{l}9 \\
7\end{array}$ & $\begin{array}{l}75 \\
58 \cdot 3\end{array}$ & $\begin{array}{l}20 \\
20 \\
20\end{array}$ & $\begin{array}{l}0 \\
0\end{array}$ & $\begin{array}{l}0 \\
0\end{array}$ \\
\hline
\end{tabular}


seminated sclerosis, two from Reiter's syndrome, and one each from cervical cord compression and retrobulbar tumour.

\section{Discussion}

When the value of a diagnostic laboratory procedure is assessed the primary consideration should be its use to the clinician in the diagnosis and control of the treatment of a disease. The technical difficulty or ease involved in the procedure must remain of secondary importance.

Whenever a new serological test for syphilis is introduced its clinical value and significance are assessed on both its sensitivity and specificity. A sensitive test, so far as the clinician is concerned, is one that will enable him to detect all cases of syphilis that presumably need treatment, while a specific test will prevent a non-syphilitic person from being labelled as having syphilis and being treated unnecessarily for it. The standard serological tests, though very useful, have not been either sufficiently sensitive or specific to meet the clinician's requirements.

When the sensitivity of the T.P.I. test is assessed and compared with standard tests according to the percentage of positive results obtained with sera from known cases of syphilis, it is found to be sensitive enough to detect syphilis at all stages beyond the early primary stage. The standard tests appear in this study to be a little more sensitive in early primary syphilis and about as sensitive as the T.P.I. test in untreated secondary and even in tertiary syphilis. In cardiovascular and neurosyphilis the T.P.I. test seems to be $100 \%$ positive while the standard tests are much less sensitive.

In latent and congenital syphilis, too, the sensitivity of the T.P.I. test is superior to the standard tests.

A diagnosis of latent syphilis is often made on the strength of positive standard tests and the patient is treated for syphilis. If the high degree of sensitivity and specificity of the T.P.I. test is eventually established by more extensive study the diagnosis of latent syphilis would be made less often and unnecessary treatment would be thereby avoided. In this study it is probable that among 101 cases labelled syphilis nine patients whose sera were negative by the T.P.I. test had been wrongly diagnosed and treated, as it is unlikely that in these cases the T.P.I. antibody would have disappeared under treatment.

Most of the syphilitic sera surveyed in this work have been from cases that have had adequate treatment. Treated cases are not so suitable for the assay of the sensitivity of these tests as untreated cases would have been. In the primary and secondary syphilis groups treatment has affected the serological reactions much more in the standard tests than in the T.P.I. test. Treatment has probably affected the results in late syphilis too, although some of the negative results obtained with standard tests may have been due to sero-negative \& late cases which are known to occur, as in cardio- $\vec{\circ}$ vascular syphilis and tabes dorsalis. It seems that, unlike the standard tests, the T.P.I. test remains $\vec{\omega}$ persistently positive after adequate treatment unless the treatment is started very early in syphilis. At its present stage of development this characteristic of the T.P.I. test makes it of little use to the clinician as a criterion of cure or in the control of $\mathbb{N}$ treatment of syphilis. A positive T.P.I. test would o mean that the patient has or has had syphilis, and the test would not enable the clinician to pick out the cases of syphilis that needed treatment. But,c of course, the result of the test has to be inter- $\frac{}{q}$ preted in conjunction with clinical findings. How $-\vec{\theta}$ ever, the quantitative standard test is still the most $f$ useful criterion to the clinician as a control of treatment.

The immobilizing antibody appears to be present in other treponemal diseases like bejel and yaws, so that the T.P.I. test may not help in distinguishing between syphilis and other treponemal diseases.

As for the specificity of the T.P.I. test, the results $\vec{O}$ obtained from the survey of non-syphilitic sera in 3 this study and the results of earlier workers (loc. cit.) indicate that the T.P.I. test is wholly specific in syphilitic infection in contrast to the standardo tests. The fact that the test is positive in other:treponemal diseases need not be a reflection on its 3 . specificity as these diseases are caused by treponemata morphologically indistinguishable froms T. pallidum.

The results obtained in the survey of 48 sera? from cases giving biological false positive reactionso for syphilis point to the particular value of the T.P.I. test as a verification test in this group of cases. With the extension of blood testing to pretv natal and pre-marital cases and in mass blood surf veys, these false positive reactions for syphilis with standard tests are more in evidence, and present difficult and interesting problems. Since the T.P.fE test is at present technically difficult and costl to perform, its main value in this country will pro bably be as a reference test in cases where a false positive reaction with the standard tests io suspected or where manifestations characteristic of late syphilis, e.g., aortitis, are present with negative standard tests. 


\section{Summary}

The clinical value of the Treponema pallidum immobilization test (T.P.I.) for syphilis has been investigated by comparing it with three standard serological tests with reference to (1) its sensitivity in 217 syphilitic sera from patients at various clinical stages of the disease; (2) its specificity in 315 non-syphilitic sera which included 109 from apparently normal persons, 48 from cases giving false positive tests for syphilis, 26 from allied treponemal diseases, and the rest from other diseases.

It has been found that the T.P.I. test is sensitive enough to detect syphilis in all stages beyond its early primary stage. The T.P.I. test remains positive indefinitely in syphilis after adequate treatment unless treatment is started very early, whereas the standard tests usually yield to treatment. A positive T.P.I. test at its present stage of development would mean that the patient has or has had syphilis, and the findings with this test may not be used as a criterion for cure or in the control of treatment.

The T.P.I. test has been rarely positive in normal persons or in diseases other than syphilis except those due to treponemata. Thus, unlike the standard tests in current use, it appears highly specific. Its greatest value at present would be as a verifica- tion test for the biological false positive reactions obtained with standard tests. The T.P.I. test is also sensitive and specific in the examination of cerebrospinal fluid in syphilitic cases.

I wish to thank Sir Alexander Fleming for laboratory facilities in the Wright-Fleming Institute of Microbiology during this investigation, Dr. C. L. M. McElligott and Dr. I. N. Orpwood Price for making available most of the specimens of serum and cerebrospinal fluid, and Professor T. B. Turner of the Johns Hopkins University School of Hygiene, Baltimore, U.S.A., for kindly supplying me with the Nichols pathogenic strain of $T$. pallidum.

\section{REFERENCES}

Adami, J. G., Andrewes, F. W., Bulloch, W., and Harrison, L. W. (1918). Spec. Rep. Ser. med. Res. Coun., Lond., No. 14.

Chacko, C. W. (1952). The treponema immobilization test for syphilis: its significance and specific value compared with standard serological tests for syphilis. Ph. D. Thesis, University of London.

Durel, P.. Sausse. A., Col!art, P., Roiron, V., and Borel, L. J. (1951) Proph. antivérér., 23, 59.

Harris, A., Rosenberg, A. A., and Riedel, L. M. (1946). J. Vener. Dis. Inform., 27, 169.

_- and Del Vecchio, E. R. (1948). Ibid., 29, 72, 313.

Kahn, R. L. (1925). Serum Diagnosis of Syphilis by Precipitation. William and Wilkins, Baltimore, U.S.A.

Magnuson, H. J., and Thompson, F. A. (1949). J. Vener. Dis. Inform. 30, 309.

Mohr, C. F., Moore, J. E., Nelson, R. A., and Hill, J. H. (1950). Amer. J. Syph., 34, 405.

Nelson, R. A., Jr., and Diesendruck, J. A. (1951). J. Immunol., 66, 667.

and Mayer, M. M. (1949). J. exp. Med., 89, 369.

Zheutlin, H. E. C., Diesendruck, J. A., and Austin, P. G. N. (1950). Amer. J. Syph., 34, 101. 